\title{
Effect of tanniferous plants on in vitro digestion and methane production
}

\section{Efecto de plantas taníferas en la digestión y producción de metano in vitro}

\author{
Raafat Mahmoud Mohamed Gomaa ${ }^{1,2}$, Manuel González-Ronquillo², Jorge Arredondo-Ramos², Luisa T. \\ Molina $^{3}$, Octavio Alonso Castelán-Ortega ${ }^{2 *}$ \\ ${ }^{1}$ Animal production department, Faculty of Agriculture, Ain Shams University, Cairo, Egypt. \\ ${ }^{2}$ Faculty of Veterinary Medicine and Animal Husbandry, Universidad Autónoma del Estado de México, Instituto Literario No. \\ 100, colonia Centro, CP 50000, Toluca, México. \\ ${ }^{3}$ Molina Center for Energy and the Environment. La Jolla, CA, USA. \\ ${ }^{*}$ Corresponding author's: oaco2002@yahoo.com.mx
}

Article Scientific received: July 12, 2016, accepted: October 31, 2016

\begin{abstract}
It has been shown that tannins in the foliage of trees and shrubs can reduce methane $\left(\mathrm{CH}_{4}\right)$ production in the rumen. The aim of the present paper was to evaluate the potential of five tanniferous browse plant species, native to temperate central Mexico, to reduce in vitro methane production. The in vitro gas production technique and gas chromatography were used to evaluate the effect of the inclusion of these plants at three inclusion levels $(10$, 20 and $30 \%)$ in an experimental diet. A factorial experimental arrangement with the five plant species and four levels of inclusion was used. Gas production was monitored throughout $72 \mathrm{~h}$ of incubation and methane production was recorded after $24 \mathrm{~h}$. The results showed that a significant decrease in methane production was observed with all plants at $10 \%$ inclusion level $(P<0.001)$, and that the highest reduction $(>26 \%)$ was observed with Amaranthus spinosus and Commelina coelestis at $20 \%$ and $30 \%$ inclusion respectively in comparison to the control diet. However, the digestibility of the experimental diet declined at these inclusion levels. It was concluded that all the tested plants reduced methane production at all inclusion levels; however, the best tradeoff between methane reduction and tannins' associated negative effects on diet digestibility was achieved at the $10 \%$ inclusion level.
\end{abstract}

Key words: Plant phenolics; Tannins; In vitro gas production; Methane emission

RESUMEN. Se ha demostrado que los taninos en el follaje de los árboles y arbustos pueden reducir la producción de metano $\left(\mathrm{CH}_{4}\right)$ en el rumen. El objetivo del estudio fue evaluar el potencial de cinco especies de plantas arbustivas, nativas de la región de clima templado del centro de México, para reducir la producción in vitro de metano. Los follajes fueron adicionados a 0,10,20 y $30 \%$ en base seca a una dieta experimental en un diseño factorial de cinco plantas por cuatro niveles de inclusión. La producción de gas in vitro se monitoreó a lo largo de 72 h de incubación y la producción de metano se registró después de $24 \mathrm{~h}$. Los resultados mostraron una disminución significativa en la producción de metano con todas las especies de plantas a un nivel de inclusión de $10 \%(\mathrm{P}<0.001)$, mientras que la reducción más alta (> $26 \%$ ) se observó con Amaranthus spinosus y Commelina coelestis a niveles de inclusión de $20 \%$ y $30 \%$, respectivamente, en comparación con la dieta control. Sin embargo, la digestibilidad de la dieta experimental disminuyó al aumentar los niveles de inclusión. Se concluyó que las plantas evaluadas en todos los niveles de inclusión redujeron la producción de metano, sin embargo el mejor balance entre la reducción en la producción de metano y los efectos negativos sobre la degradación de la dieta asociados a los taninos se alcanzó a un nivel de inclusión del $10 \%$.

Palabras clave: Fenoles; Taninos; Producción de gas in vitro; Metano; Nutrición 


\section{INTRODUCTION}

The accumulation of greenhouse gases ( $\mathrm{GHG}$ ) such as $\left(\mathrm{CO}_{2}\right)$, methane $\left(\mathrm{CH}_{4}\right)$ and nitrous oxide $\left(\mathrm{N}_{2} \mathrm{O}\right)$ in the Earth's atmosphere has led to predictions that global surface temperatures will increase between one and six degrees Celsius during the 21st century (IPCC 2007). According to Arbre et al. (2016), the contribution of livestock to anthropogenic GHG emissions is estimated at $14.5 \%$ of total emissions, of which $39 \%$ is due to methane $\left(\mathrm{CH}_{4}\right)$ produced by enteric fermentation in ruminants. Approximately $6 \%$ of cattle dietary gross energy intake is lost to the atmosphere in the form of methane (De Ramus et al. 2003). Hence, mitigating methane emissions could improve sustainability and profitability of cattle enterprises (Vanlierde et al. 2016). Historically, the inhibition of enteric methanogenesis has been approached in regard to livestock nutrition. More recently the reduction of $\mathrm{CH}_{4}$ formation has garnered interest in relation to reducing $\mathrm{GHG}$ emissions. Previous studies have reported that $\mathrm{CH}_{4}$ production can be reduced by the addition of plant extracts containing tannins to livestock feed (Patra et al. 2006, Patra et al. 2010). A meta-analysis by Jayanegara et al. (2012) showed that condensed and hydrolysable tannins may reduce $\mathrm{CH}_{4}$ production. Tannins may directly affect methanogenesis by inhibiting the growth, development and activity cellulase enzyme of methanogens, or indirectly by reducing the number of protozoa associated with the methanogens (Makkar et al. 1993). Tanniferous plants can represent a sustainable and environmentally friendly option for mitigation; however, significant screening work is needed in order to find the most efficient species. These species have to meet two criteria, one is to reduce $\mathrm{CH}_{4}$ formation in the rumen and the other is to not diminish animal performance through modification of feedstuffs' fermentation and digestibility in the rumen. In vivo evaluation of different species can be expensive and not feasible due to the large number of plants that need to be evaluated. Therefore, in vitro gas production can be used as a screening test to select the species with the greatest potential before in vivo evaluation. The objective of the study was to evaluate the potential use of five Mexican tanniferous shrub plants to reduce methane emission and measure the effect on digestibility of the dry matter, organic matter and neutral detergent fiber in the diet, using the in vitro gas production technique and gas chromatography.

\section{MATERIALS AND METHODS}

The study was conducted at the animal nutrition laboratory of the Faculty of Veterinary Medicine of the Autonomous University of the State of Mexico, and complied with the ethical standards set by the institution.

\section{Sample collection and preparation}

The browse plant species used in the study were Amaranthus spinosus, Cosmos bipinnatus, Commelina coelestis, Eupatorium glabratum and Galinsoga parviflora. Plant samples were collected from six different locations randomly selected in the temperate region of the State of Mexico, located at $19^{\circ} 17^{\prime} 32^{\prime \prime} \mathrm{N}$ and $99^{\circ} 39^{\prime} 14^{\prime \prime} \mathrm{W}$ and at 2663 masl. For each species, six kilograms of fresh plant matter (one for each location) were collected and cut into small pieces $(3-5 \mathrm{~cm})$. Samples were then dried at $50^{\circ} \mathrm{C}$ for $48 \mathrm{~h}$ using a forced air oven in order to prevent enzymatic degradation of the phenolic compounds present in the plant matter (Makkar et al. 1993). Once dry, $400 \mathrm{~g}$ of plant matter were ground in a Lab-Willey Grinder (code MSW-342IN; 10122740) and sieved through a 2-mm screen. The grounded material was mixed well and then 100 $\mathrm{g}$ were sub-sampled, reground and passed through a $0.5-\mathrm{mm}$ screen sieve. These finely ground subsamples were used in tannin analysis while the rest of the material was used for in vitro gas production analysis.

\section{Treatments}

The experimental diet (control) was composed of $64.6 \%$ ryegrass (Lolium perenne), $20.8 \%$ corn grain (Zea mays), $8.3 \%$ canola meal (Brassica napus) and $6.3 \%$ corn stover. In the experimen- 
tal treatments $0,10,20$ and $30 \%$ ryegrass was replaced by equivalent amounts of the test plants; thus, 20 treatments were tested.

\section{Chemical composition of plants}

Dry matter (DM) was determined by drying the samples at $135{ }^{\circ} \mathrm{C}$ for $2 \mathrm{~h}$. Organic matter (OM) was calculated as weight lost at sample ignition at $600{ }^{\circ} \mathrm{C}$ (AOAC 1995). Neutral detergent fiber (NDF) and acid detergent fiber (ADF) were determined using the ANKOM fiber technology technique (Robinson et al. 1999) without using alpha amylase. Crude protein (CP) was determined by the Kjeldahl method (AOAC 1995).

\section{In vitro gas production}

Gas production (GP) was determined following the Theodorou et al. (1994) technique. Rumen fluid was collected before the morning feeding from two ruminally-fistulated, non-lactating and non-gravid Holstein cows. All cows had access to fresh water at all times, were fed the same experimental diet, and grazed on a ryegrass sward from 6:00 until 16:00 $\mathrm{h}$ daily. Samples weighing $0.999 \mathrm{~g}$ of the control and experimental diets were placed in $125-\mathrm{ml}$ serum glass bottles, and approximately $90 \mathrm{ml}$ of buffered rumen fluid was added to each bottle. Once closed, the bottles were gently shaken and placed in a water bath at $39{ }^{\circ} \mathrm{C}$. Six independent runs were completed. The first three were incubated for $24 \mathrm{~h}$ in order to simulate normal residence time of feed in the rumen, and were used to measure methane production at $24 \mathrm{~h}$ postincubation. The other three runs were incubated for $72 \mathrm{~h}$. A total of 288 bottles were used and all incubations were completed in triplicate within the run. Gas production measurements, for the samples incubated $72 \mathrm{~h}$, were taken hourly (up to $8 \mathrm{~h}$ postincubation), then every four (12- 28), eight (3660 ) and $72 \mathrm{~h}$ post-incubation. After 24 and $72 \mathrm{~h}$, the incubation residue was analyzed for digestibility of dry matter (DMD), organic matter (OMD) and neutral-detergent fiber (DNDF) content using the ANKOM fiber technology technique (Robinson et al. 1999).

\section{Methane measurement}

Using a gas-tight syringe, gas samples were collected from each bottle at $24 \mathrm{~h}$ post-incubation as in Bhatta et al. (2015) and Kaya et al. (2016). After the volume of gas was recorded, and the sample removed for methane analysis, the remaining gas was released. $\mathrm{CH}_{4}$ content was determined by injecting $1 \mathrm{ml}$ of gas into a Perkin Elmer gas chromatograph (model: Clarus 500 series) equipped with a flame ionized detector (FID). Separation was achieved using an Elite-Q Plot Capillary Column (Perkin Elmer) packed with a 60/80 mesh carboxenTM-1000 stationary phase. Nitrogen was used as the carrier gas with a flow rate of $30 \mathrm{~mL}^{-1} \mathrm{~min}$, an isothermal oven temperature of $50{ }^{\circ} \mathrm{C}$, and an injector temperature of 250 ${ }^{\circ} \mathrm{C}$. The calibration curve using a regression equation was completed with standard $\mathrm{CH}_{4}(99.99 \%$ from ALTECH).

\section{Extraction of tannins and measurement of to-} tal phenolics and tannins content

Phenols content was determined using the Folin-Ciocalteu method and tannins were measured using polyvinylpolypyrrolidone (PVPP) as described by Makkar et al. (1993).

\section{Experimental design and analysis of results}

A completely randomized design with a $5 \times 4$ factorial arrangement was used in which both the plants used and their inclusion levels are treatments. The general linear model was:

$$
Y i j=\mu+T i+B j+(T i * B j)+e i j
$$

Where: $\mathrm{Yij}=$ independent variable, $\mu=$ overall mean, $\mathrm{T} i=$ effect of plant $(i=1 \ldots 5), \mathrm{Bj}=$ effect of the level of inclusion $(j=1 \ldots 4),(T i * B j)=E f-$ fect of the interaction between plant species and the level of inclusion and eij= True error in the $i$ level inclusion of $\mathrm{j}$ treatment.

Results were analyzed with analysis of variance using the general linear model command of Minitab (2013) for a factorial experimental design; 
Table 1. Chemical composition, Phenols and tannins content of the experimental diet and plant species ( $\left.\mathrm{g} \mathrm{kg}^{-1} \mathrm{DM}\right)$.

\begin{tabular}{llllllllll}
\hline Feed & $\begin{array}{l}\text { Dry } \\
\text { matter }\end{array}$ & $\begin{array}{l}\text { Organic } \\
\text { matter }\end{array}$ & $\begin{array}{l}\text { Crude } \\
\text { protein }\end{array}$ & NDF & ADF & $\begin{array}{l}\text { Total } \\
\text { phenols } \\
\mathrm{N}\end{array}$ & $\begin{array}{l}\text { on- } \\
\text { tannins } \\
\text { phenols }\end{array}$ & $\begin{array}{l}\text { Total } \\
\text { tannins }\end{array}$ & $\begin{array}{l}\text { Condensed } \\
\text { tannins }\end{array}$ \\
\hline Diet & $909^{b d}$ & $810^{d}$ & $160^{e}$ & $439^{a}$ & $181^{e}$ & $34.4^{f}$ & $11.2^{a}$ & $22.2^{c}$ & $1.19^{d}$ \\
Amaranthus spinosus & $930^{a}$ & $760^{a}$ & $184^{a}$ & $448^{a}$ & $220^{a}$ & $48.4^{a}$ & $10.9^{a}$ & $37.5^{a}$ & $5.5^{a}$ \\
Cosmos bipinnatus & $901^{c b}$ & $810^{b}$ & $84^{b}$ & $481^{b}$ & $327^{b}$ & $90.7^{b}$ & $19.0^{b}$ & $71.7^{b}$ & $8.4^{b}$ \\
Commelina coelestis & $926^{a d}$ & $780^{c}$ & $93^{c}$ & $550^{c}$ & $360^{c}$ & $32.3^{c}$ & $11.2^{a}$ & $21.1^{c}$ & $5.4^{a}$ \\
Ebatorium glabratium & $928^{a}$ & $824^{b}$ & $100^{c}$ & $370^{d}$ & $209^{a}$ & $11.2^{d}$ & $11.3^{a}$ & $18.2^{d}$ & $0.6^{c}$ \\
Galinosa parviflora & $918^{a c}$ & $809^{b d}$ & $109^{d}$ & $488^{b}$ & $306^{d}$ & $11.3^{e}$ & $17.3^{b}$ & $43.2^{e}$ & $1.0^{d}$ \\
\hline
\end{tabular}

$\mathrm{NDF}=$ neutral detergent fiber, $\mathrm{ADF}=$ Acid detergent fiber, ${ }^{a, b, c, d, e, f}$ Different superscripts following means between plants species' in the row indicate differences at $\mathrm{p}<0.05$.

where significant differences between species and level were found, a Tukey test was applied. Individual analysis of variance for level within species was also conducted using a completely randomized design for a significance level of $p<0.05$; where significant differences between levels were found, a Tukey test was also applied. The GP curves were not fitted to mathematical models in order to determine fermentation kinetics because the aim of the work was not to describe the effect of tanniferous plants on diet's kinetics, but their effect on reducing methane production in the rumen. We used a simpler, original and intuitive approach; we wanted to know the volume of gas produced from the feed sample in order to have an indicator of the extent of digestion (fermentation) of the diet in the rumen (bottles). The results were analyzed by ANOVA as described above.

\section{RESULTS}

Chemical composition and polyphenols contents: Table 1 shows the chemical composition of the experimental diet and plant species. The highest $\mathrm{CP}$ content was observed in $A$. spinosus $(p<0.05)$, followed by $G$. parviflora. It can also be observed that the NDF content for all analyzed plant species is moderate. Table 1 also shows the content (g kg-1 DM) of total phenols, non-tannin phenols, total tannins and condensed tannins for all the experimental plants used. It can be observed that the highest concentration of total tannins ( $p$ $<0.05$ ) was in $C$. bipinnatus, and the lowest in E. glabratium. The highest concentration of con- densed tannins $(p<0.05)$ was also observed in $C$. bipinatus, followed by $A$. spinosus and $C$. coelestis, both with the same content.

Gas and methane production: Table 2 shows the $\mathrm{CH}_{4}$ production after $24 \mathrm{~h}$ of fermentation and the cumulative volume of gas produced at 24 and 72 $h$ of fermentation for the five species at the different inclusion levels. The inclusion of all plant species $(p<0.001)$ at all inclusion levels resulted in a significant reduction $(p<0.001)$ of methane produced. Individual analysis by species shows that the highest reduction in methane production (26.2 $\%)$ was observed when $C$. coelestis was included at a level of $30 \%(\mathrm{p}<0.05)$ followed by including $A$. spinosus at $20 \%$ (26\% less $\mathrm{CH}_{4}$ produced). The other three plants also significantly reduced ( $\mathrm{p}<$ $0.05) \mathrm{CH}_{4}$ production by $20 \%$ when included at $30 \%$ level. Further, G. parviflora and $A$. spinosus reduced methane production by $15 \%$ and $17 \%$, respectively, when included at $10 \%$ level.

The cumulative gas produced after $72 \mathrm{~h}$ of incubation for all five species at all inclusion levels followed the same trend as did the gas produced at $24 \mathrm{~h}$ of incubation; for example, the highest volume of gas produced was observed with $C$. coelestis at $20 \%$ inclusion level $(p<0.05)$ for both incubation periods. The inclusion of $A$. spinosus, $C$. bipinatus and $\mathrm{G}$. perviflora at $30 \%$ level and at $24 \mathrm{~h}$ of incubation did not reduce gas production $(p<0.05)$. On the contrary, $C$. coelestis and E. Glabratium reduced $(p<0.05)$ gas production at the same level of inclusion. The overall statistical analysis column in Table 2 shows that the inclusion levels 
Table 2. Effect of the inclusion of five tanniferous plant species on methane production at $24 \mathrm{~h}$ and cumulative gas production at 24 and $72 \mathrm{~h}$ of incubation.

\begin{tabular}{|c|c|c|c|c|c|c|c|c|c|}
\hline $\begin{array}{l}\text { Inclusion } \\
\text { level }\end{array}$ & $\begin{array}{c}\text { Amaranthus } \\
\text { spinosus }\end{array}$ & $\begin{array}{c}\text { Species } \\
\text { Cosmos } \\
\text { bipinnatus }\end{array}$ & $\begin{array}{c}\text { Commelina } \\
\text { coelestis }\end{array}$ & $\begin{array}{l}\text { Ebatorium } \\
\text { glabratium }\end{array}$ & $\begin{array}{l}\text { Galinosa } \\
\text { parviflora }\end{array}$ & $\bar{x}$ for level & $\begin{array}{l}\mathrm{P} \text { value } \\
\text { Species }\end{array}$ & Level & Interaction \\
\hline \multicolumn{10}{|c|}{ Methane production $\left(\mathrm{ml}\right.$ of $\left.\mathrm{CH}_{4} \mathrm{~g}^{-1} \mathrm{DM}\right)$} \\
\hline $0 \%$ & $65.6^{a}$ & $65.6^{a}$ & $65.6^{a}$ & $65.6^{a}$ & $65.6^{a}$ & $65.6^{a}$ & 0.001 & 0.002 & 0.008 \\
\hline $10 \%$ & $55.8^{b}$ & $58.0^{b}$ & $56.1^{b}$ & $56.9^{b}$ & $54.3^{b}$ & $56.2^{b}$ & & & \\
\hline $20 \%$ & $48.5^{c}$ & $59.2^{b}$ & $63.5^{a}$ & $57.6^{b}$ & $55.4^{b c}$ & $56.8^{b}$ & & & \\
\hline $30 \%$ & $58.3^{b}$ & $52.0^{c}$ & $48.4^{c}$ & $52.3^{c}$ & $52.9^{b}$ & $52.7^{c}$ & & & \\
\hline $\bar{x}$ for species & $57.0^{a}$ & $58.7^{b}$ & $58.4^{b}$ & $58.1^{b}$ & $57.0^{a}$ & & & & \\
\hline SED & & & & & & & 0.54 & 0.49 & \\
\hline \multicolumn{10}{|c|}{ Gas production at $24 \mathrm{~h}\left(\mathrm{ml} \mathrm{g}^{-1} \mathrm{DM}\right)$} \\
\hline $0 \%$ & $177.9^{a}$ & $177.9^{a}$ & $177.9^{a}$ & $177.9^{a}$ & $177.9 \mathrm{a}$ & $177.9^{a}$ & 0.001 & 0.072 & 0.001 \\
\hline $10 \%$ & $170.2^{a}$ & $180.1^{a}$ & $186.3^{a b}$ & $168.5^{b}$ & $183.2^{a b}$ & $177.6^{a}$ & & & \\
\hline $20 \%$ & $149.8^{b}$ & $183.4^{a b}$ & $186.7 \mathrm{~b}$ & $170.5^{b c}$ & $181.4^{a}$ & $174.3^{a}$ & & & \\
\hline $30 \%$ & $177.9^{a}$ & $164.4^{a c}$ & $160.9 c$ & $163.9^{b}$ & $175.8^{a d}$ & $168.5^{b}$ & & & \\
\hline $\bar{x}$ for species & $169.0^{a}$ & $176.4^{b}$ & $178.0^{c}$ & $170.2^{a}$ & $179.5^{d c}$ & & & & \\
\hline SED & & & & & & & 1.7 & 1.53 & \\
\hline \multicolumn{10}{|c|}{ Gas production at $72 \mathrm{~h}\left(\mathrm{ml} \mathrm{g}^{-1} \mathrm{DM}\right)$} \\
\hline $0 \%$ & $265.1^{a}$ & $265.1^{a}$ & $265.1^{a}$ & $265.1^{a}$ & $265.1^{a}$ & $265.0^{a}$ & 0.001 & 0.067 & 0.001 \\
\hline $10 \%$ & $246.9^{b}$ & $258.4^{b}$ & $270.9^{a}$ & $249.7^{b}$ & $256.5^{d}$ & $256.4^{b}$ & & & \\
\hline $20 \%$ & $221.8^{c}$ & $264.5^{a}$ & $276.7^{a}$ & $250.1^{b}$ & $251.7^{b d}$ & $253.0^{c b}$ & & & \\
\hline $30 \%$ & $268.4^{a}$ & $250.8^{c}$ & $249.0^{b}$ & $241.6^{c}$ & $248.0^{c d}$ & $251.5^{d b}$ & & & \\
\hline $\bar{x}$ for species & $250.5^{a}$ & $259.6^{b}$ & $265.4^{c}$ & $251.6^{a}$ & $255.3^{a}$ & & & & \\
\hline SED & & & & & & & 2.2 & 1.9 & \\
\hline
\end{tabular}

of all plant species did not significantly reduce gas production for both incubation periods, $\mathrm{p}>0.07$ and $\mathrm{p}>0.06$, respectively. By contrast, significant differences were observed between species ( $p$ $<0.001$ ), with the largest gas production volumes being observed in $C$. coelestis and $G$. parviflora.

Effect on the digestibility of the diet: Table 3 shows the digestibility $\left(\mathrm{g} \mathrm{kg}^{-1} \mathrm{DM}\right)$ of the DM, OM and NDF at $24 \mathrm{~h}$ of incubation for all species at all inclusion levels. The DMD and the OMD of the experimental diet was reduced by all species at all inclusion levels ( $p<0.001$ ) except for $G$. parviflora at $30 \%$ inclusion where no change was observed in DMD $(p>0.05)$. However, OMD and DNDF were not affected when using C. bipinnatus at $20 \%$ inclusion level $(p>0.05)$ (Table 3$)$. This may be an important indicator that this plant can decrease methane production in vivo but not the overall digestive ability of cattle. In contrast, $C$. coelestis significantly reduced DMD, OMD and DNDF at 30 $\%$ inclusion level, which was accompanied by the highest reduction of methane production in the ex- perimental diet (Table 2). The DNDF increased by the inclusion of all plant species at inclusion level of $10 \%$ at $24 \mathrm{~h}$ of incubation but at the $30 \%$ level it decreased DNDF $(\mathrm{p}<0.001)$. Table 4 shows the digestibility $\left(\mathrm{g} \mathrm{kg}^{-1} \mathrm{DM}\right)$ of the DM, OM and NDF after $72 \mathrm{~h}$ of incubation for all species at all inclusion levels. A trend similar to that in Table 3 was observed, since the inclusion of all plants at all levels resulted in a significant reduction of the DNDF ( $p$ $<0.001$ ). Figure 1 shows the effect of interaction between plant species and the inclusion levels on methane production at $24 \mathrm{~h}(\mathrm{p}<0.001)$; it can be observed that the response is not linear for all the species because a quadratic effect was observed for $A$. spinosus, $C$. bipinnatus and $C$. coelestis. All plants reduced methane production at $10 \%$ inclusion but at $20 \%$ only Amaranthus spinosus, Cosmos bipinnatus, Eupatorium glabratum and Galinsoga parviflora kept methane production low. However, a significant interaction can be observed at level three for A. spinosus ( $p<0.001), C$. bipinnatus ( $p$ $<0.01)$ and $C$. coelestis $(p<0.001)$ because lines of these species are not parallel implying that the 


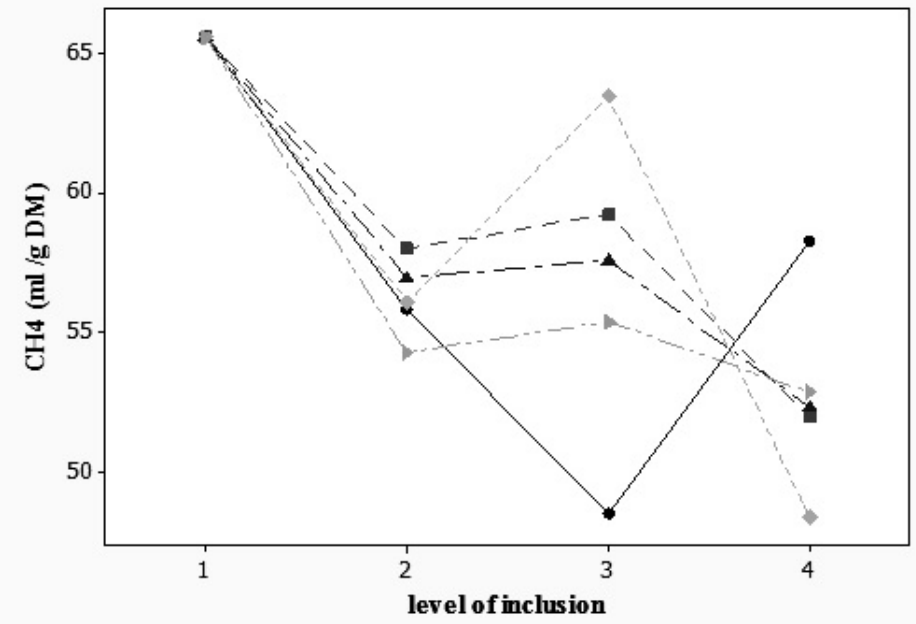

Figure 1. Interaction plot for methane production at $24 \mathrm{~h}$ of incubation for the five tanniferous species at the different inclusion levels.

Table 3. Effect of the inclusion of five tanniferous plant species on the digestibility of dry matter, organic matter and NDF after $24 \mathrm{~h}$ of incubation $\left(\mathrm{g} \mathrm{kg}^{-1} \mathrm{DM}\right)$.

\begin{tabular}{|c|c|c|c|c|c|c|c|c|c|}
\hline $\begin{array}{l}\text { Inclusion } \\
\text { level }\end{array}$ & $\begin{array}{c}\text { Amaranthus } \\
\text { spinosus }\end{array}$ & $\begin{array}{c}\text { Cosmos } \\
\text { bipinnatus }\end{array}$ & $\begin{array}{c}\text { Plant Species } \\
\text { Commelina } \\
\text { coelestis }\end{array}$ & $\begin{array}{l}\text { Ebatorium } \\
\text { glabratium }\end{array}$ & $\begin{array}{c}\text { Galinosa } \\
\text { parviflora }\end{array}$ & $\bar{x}$ for level & $\begin{array}{l}\mathrm{P} \text { value for } \\
\text { Species }\end{array}$ & Level & Interaction \\
\hline \multicolumn{10}{|c|}{ Dry matter digestibility } \\
\hline $0 \%$ & $739^{a}$ & $739^{a}$ & $739^{a}$ & $739^{a}$ & $739^{a}$ & $739.3^{a}$ & 0.001 & 0.001 & 0.001 \\
\hline $10 \%$ & $673^{b}$ & $683^{b}$ & $719^{b}$ & $701^{b}$ & $628^{b}$ & $681.0^{b}$ & & & \\
\hline $20 \%$ & $686^{c}$ & $732^{c}$ & $726^{c}$ & $717^{c}$ & $680^{d}$ & $708.0^{c}$ & & & \\
\hline $30 \%$ & $723^{d}$ & $649^{d}$ & $621^{d}$ & $705^{b}$ & $744^{a}$ & $688.4^{d}$ & & & \\
\hline $\bar{x}$ for species & $705.3^{a}$ & $700.7^{b}$ & $701.2^{c b}$ & $715.5^{d}$ & $698.0^{e b}$ & & & & \\
\hline SED & & & & & & & 1.4 & 1.3 & \\
\hline \multicolumn{10}{|c|}{ Organic matter digestibility } \\
\hline $0 \%$ & $742^{a}$ & $742^{a}$ & $742^{a}$ & $742^{a}$ & $742^{a}$ & $742.4^{a}$ & 0.001 & 0.001 & 0.001 \\
\hline $10 \%$ & $679^{b}$ & $693^{b}$ & $728^{b}$ & $710^{b}$ & $638^{b}$ & $689.5^{b}$ & & & \\
\hline $20 \%$ & $690^{c}$ & $740^{a}$ & $731^{b}$ & $729^{a c}$ & $692^{c}$ & $716.5^{c}$ & & & \\
\hline $30 \%$ & $728^{d}$ & $659^{d}$ & $631^{c}$ & $716^{b c}$ & $753^{d}$ & $697.4^{d}$ & & & \\
\hline $\bar{x}$ for species & $710.0^{a}$ & $708.6^{a}$ & $708.0^{a}$ & $724.5^{b}$ & $706.2^{a}$ & & & & \\
\hline SED & & & & & & & 1.6 & 1.4 & \\
\hline \multicolumn{10}{|c|}{ Digestibility of Neutral detergent fiber } \\
\hline $0 \%$ & $657^{a}$ & $657^{a}$ & $657^{a}$ & $657^{a}$ & $657^{a}$ & $657.1^{a}$ & 0.001 & 0.001 & 0.001 \\
\hline $10 \%$ & $680^{b}$ & $725^{b}$ & $655^{a}$ & $665^{a}$ & $715^{b}$ & $688.0^{b}$ & & & \\
\hline $20 \%$ & $656^{a}$ & $686^{a c}$ & $680^{b}$ & $634^{c}$ & $652^{a b}$ & $661.5^{a}$ & & & \\
\hline $30 \%$ & $643^{a}$ & $651 a^{d}$ & $624^{c}$ & $582^{b}$ & $662^{a b}$ & $632.3^{c}$ & & & \\
\hline $\bar{x}$ for species & $659.0^{a}$ & $679.5^{b}$ & $654.0^{a}$ & $634.6^{c}$ & $671.3^{a b}$ & & & & \\
\hline
\end{tabular}

SED is standard error of difference, ${ }^{a, b, c, d}$ Different superscripts following means within plant species' inclusion levels in the column indicate differences at $\mathrm{p}<0.05$.

effect of the species upon $\mathrm{CH}_{4}$ production depends up on the inclusion level. Moreover, the inclusion level effect explains more than two and a half times the total variance explained by the species.

\section{DISCUSSION}

\section{Polyphenols content}

In the present study, we found significantly lower levels of methane released with increasing levels of most tannin-rich plants added to the ex- 
Table 4. Effect of the inclusion levels of the five plant species on digestibility of dry matter, organic matter and NDF after $72 \mathrm{~h}$ of incubation ( $\left.\mathrm{g} \mathrm{kg}^{-1} \mathrm{DM}\right)$.

\begin{tabular}{|c|c|c|c|c|c|c|c|c|c|}
\hline $\begin{array}{l}\text { Inclusion } \\
\text { level }\end{array}$ & $\begin{array}{c}\text { Amaranthus } \\
\text { spinosus }\end{array}$ & $\begin{array}{c}\text { Cosmos } \\
\text { bipinnatus }\end{array}$ & $\begin{array}{c}\text { Plant Species } \\
\text { Commelina } \\
\text { coelestis }\end{array}$ & $\begin{array}{l}\text { Ebatorium } \\
\text { glabratium }\end{array}$ & $\begin{array}{c}\text { Galinosa } \\
\text { parviflora }\end{array}$ & $\bar{x}$ for level & $\begin{array}{l}\mathrm{P} \text { value for } \\
\text { Species }\end{array}$ & Level & Interaction \\
\hline \multicolumn{10}{|c|}{$\begin{array}{l}\text { Dry matter digestibility } \\
\end{array}$} \\
\hline $0 \%$ & 814 & $814^{a}$ & $814 a$ & $814 a$ & 814a & $814.0 a$ & 0.001 & 0.001 & 0.001 \\
\hline $10 \%$ & 823 & $794^{b}$ & $793 b$ & $769 b$ & $839 b$ & $804.0 \mathrm{~b}$ & & & \\
\hline $20 \%$ & 812 & $817^{a}$ & 799ab & 794ab & $839 b$ & $812.6 a$ & & & \\
\hline $30 \%$ & 808 & $788^{b}$ & $766 c$ & $765 b$ & $819 a b$ & $789.3 c$ & & & \\
\hline $\bar{x}$ for species & $814.0 a$ & $803.6 a$ & $793.0 \mathrm{~b}$ & $786.0 \mathrm{cb}$ & $828.0 \mathrm{~d}$ & & & & \\
\hline SED & & & & & & & 3.9 & 3.6 & \\
\hline \multicolumn{10}{|c|}{ Organic matter digestibility } \\
\hline $0 \%$ & $821^{a}$ & $821^{a}$ & $821^{a}$ & $821^{a}$ & $821^{a}$ & $820^{a}$ & 0.001 & 0.001 & 0.001 \\
\hline $10 \%$ & $843^{b}$ & $799^{b}$ & $797^{b}$ & $778^{a}$ & $847^{b}$ & $813^{a}$ & & & \\
\hline $20 \%$ & $824^{a}$ & $821^{a}$ & $801^{a b}$ & $808^{a}$ & $847^{b}$ & $820^{a}$ & & & \\
\hline $30 \%$ & $821^{a}$ & $799^{b}$ & $774^{c}$ & $773^{b}$ & $833^{a b}$ & $800^{b}$ & & & \\
\hline $\bar{x}$ for species & $827.0 \mathrm{a} 810.0^{b}$ & $798.3^{c b}$ & $795.0^{d c}$ & $837.0^{a}$ & & & & & \\
\hline SED & & & & & & & 4.9 & 4.3 & \\
\hline \multicolumn{10}{|c|}{ Digestibility of Neutral detergent fiber } \\
\hline $0 \%$ & $755^{a}$ & $755^{a}$ & $755^{a}$ & $755^{a}$ & $755^{a}$ & $754.7^{a}$ & 0.001 & 0.001 & 0.001 \\
\hline $10 \%$ & $779^{b}$ & $728^{b}$ & $726^{b}$ & $698^{b}$ & $774^{a b}$ & $740.7^{b}$ & & & \\
\hline $20 \%$ & $704^{c}$ & $715^{b}$ & $719^{b}$ & $667^{c}$ & $748^{a}$ & $710.5^{c}$ & & & \\
\hline $30 \%$ & $685^{c}$ & $658^{c}$ & $674^{c}$ & $579^{d}$ & $742^{a c}$ & $667.6^{d}$ & & & \\
\hline $\bar{x}$ for species & $730.6 a$ & $714.0^{b}$ & $718.2^{c b}$ & $674.7^{d}$ & $754.3^{e}$ & & & & \\
\hline
\end{tabular}

perimental diet. Tannins were frequently observed to reduce structural carbohydrate digestibility by decreasing the number of cellulolytic microbes in rumen fluid (Singleton 1981), inhibiting cellulase enzyme activity (Leinmüller et al. 1991, Makkar 1993), preventing adhesion of microbes onto food particles (Leinmüller and Menke 1990) and/or suppressing degradation by the formation of complexes with cellulose (McSweeney et al. 2001). However, no information is given by these authors as to whether there is a difference between the effects of hydrolysable and condensed tannins, but Leinmüller et al. (1991) considered hydrolysable tannins as being less adverse in this respect. It is worth mentioning that the effect of tannins on DNDF was not the same for all species at $10 \%$ inclusion level ( $\mathrm{Ta}$ ble 3); for example, the DNDF for $A$. spinosus, and $G$. parviflora increased at this level. This suggests that at low inclusion levels these plants may reduce methane production without significantly affecting the DNDF.

\section{Methane production}

Results of the present study show that methane was consistently reduced by all five tanniferous plants (Table 2), and that the highest reduction was observed by the inclusion of $C$. coelestis and $A$. spinosus at the 30 and $20 \%$ inclusion levels respectively. The same effect of tannin-rich plants was observed by Hatew et al. (2016) and Rodríguez et al. (2011) who reported reduced methane production with the addition of plant extract containing tannins. The concentration of condensed tannins in both plants species may have also exerted a negative effect on methane production because $C$. coelestis and $A$. spinosus showed the second highest concentrations of condensed tannins just behind $C$. bipinatus. These results are in line with Tavendale et al. (2005) and Gemeda and Hassen (2015) who demonstrated for the first time that condensed tannins can inhibit methane production by inhibiting the growth of rumen methanogens and by their indirect effects via reduced hydrogen production (possible by reducing fiber digestibility). In the present study, the largest reduction in methane production observed with the inclusion of $C$. coelestis was accompanied by a sig- 
nificant reduction in the DNDF at $30 \%$ inclusion level (Tables 2 and 3), which confirms the Gemeda and Hassen (2015) hypothesis. Our results are also in line with Tan et al. (2011) who found that a relatively low level of $15 \mathrm{mg}$ of condensed tannins/500 $\mathrm{mg}$ of DM reduced methane production by $47 \%$ with only $7 \%$ reduction in digestibility of feed DM. No information was found in the literature reviewed on the effect of the plants analysed in the present work on methane production, so no further discussion was possible.

\section{Gas production}

Gas production is generally recognized as a more sensitive approach for detection of differences in substrate fermentation using in vitro systems than DM disappearance ( $\mathrm{Xu}$ et al. 2010). Our results show that GP was negatively affected by some levels of inclusion of tanniferous plants in the experimental diet (Table 2). This effect could be attributed to the antimicrobial properties of tannins and phenolic compounds in the experimental plants, which in turn cause a reduction in gas production (Francis et al. 2002). However, the least severe effect on GP was observed at $10 \%$ inclusion level suggesting that the best tradeoff between methane reduction and reduction of diet digestibility can be achieved at low inclusion levels of these plants.

\section{Interaction plant species $\mathrm{x}$ inclusion rate}

The significant interaction observed between inclusion level and plant species for methane and gas production indicates that the behaviors of both variables are the result of the combined effect between the plant species and, particularly, the inclusion level of it in the diet. This effect is clearly seen in the case of $C$. bipinnatus and $C$. coelestis, where at low inclusion level the effect on methane production is moderate; however, at the highest inclusion rate methane production is drastically reduced due to the effect of tannins, especially condensed ones since both plants have a high content of these secondary metabolites. Unfortunately, methane reduction was accompanied by a significant reduction in DMD and OMD, which may prevent the inclusion of these plants at high rates in in vivo experiments.

\section{CONCLUSION}

It is concluded that all the tested plants reduced methane production at all inclusion levels; however, the best tradeoff between methane reduction versus negative effects on diet digestibility was achieved at the low and intermediate rather than highest inclusion levels. In this way the most promising result was observed for $A$. spinosus and C. bipinnatus. The impact of this inhibition on ruminant whole-animal energy needs to be evaluated in vivo in order to use these plants in sustainable methane mitigation strategies provided they show the same effects as in vitro.

\section{ACKNOWLEDGMENTS}

The authors acknowledge the financial support from the Molina Center for Energy and the Environment (under UNEP Contract GFL-4C58) and the Universidad Autónoma del Estado de México (grant UAEM 3474/2013CHT), which made the present work possible. Mr. Raafat M. M. Gomaa thanks the National Council for Science and Technology (CONACYT, Mexico) for the scholarship for his $\mathrm{PhD}$.

\section{LITERATURE CITED}

Arbre M, Rochette Y, Guyader J, Lascoux C, Gómez LM, Eugène M et al. (2016) Repeatability of enteric methane determinations from cattle using either the SF6 tracer technique or the GreenFeed system. Animal Production Science 56: 238-243.

AOAC (1995) Association of Official Analytical Chemists. Official Methods of Analysis, 16th ed., Arlington, VA, USA. 
Bhatta R, Saravanan M, Baruah L, Prasad CS (2015) Effects of graded levels of tannin-containing tropical tree leaves on in vitro rumen fermentation, total protozoa and methane production. Journal of Applied Microbiology 118: 557-564.

De Ramus HA, Clement TC, Giampola DD, Dickison PC (2003) Methane emissions of beef cattle on forages: efficiency of grazing management systems. Journal of Environment Quality 32: 269-277.

Francis G, Kerem Z, Makkar HP, Becker K (2002) The biological action of saponins in animal systems: a review. British Journal of Nutrition 88: 587-605.

Gemeda BS, Hassen A (2015) Effect of tannin and species variation on in vitro digestibility, gas, and methane production of tropical browse plants. Asian-Australasian Journal of Animal Science 28: 188-199.

Hatew B, Stringano E, Mueller-Harvey I, Hendriks WH, Carbonero CH, Smith LMJ et al (2016) Impact of variation in structure of condensed tannins from sainfoin (Onobrychis viciifolia) on in vitro ruminal methane production and fermentation characteristics. Journal of Animal Physiology and Animal Nutrition 100: 348-360.

IPCC (2007) Intergovernmental Panel on Climate Change. Climate change 2007: The physical science basis. In: Solomon S, Qin D, Manning M, Chen Z, Marquis M, Averyt KB, Tignor M, Miller HL (Eds). Contribution of working group I to the fourth assessment report of the intergovernmental panel on climate change. Cambridge University Press, Cambridge, United Kingdom and New York, USA. 996p.

Jayanegara A, Leiber F, Kreuzer M (2012) Meta-analysis of the relationship between dietary tannin level and methane formation in ruminants from in vivo and in vitro experiments. Journal of Animal Physiology and Animal Nutrition 96: 365-375.

Kaya E, Canbolat O, Atalay AI, Kurt O, Kamalak A (2016) Potential nutritive value and methane production of pods, seed and senescent leaves of Gleditsia triacanthos trees. Livestock Research for Rural Development, 28(7): 123. http://www.lrrd.org/lrrd28/7/kama28123.html. Date consulted: june 25, 2016.

Leinmüller E, Menke KH (1990) Tannine in Futtermitteln für Wiederkäuer. 1. Chemische Eigenschaften und Reaktionen mit Makromolekülen. Übers. Tierernähr 18: 91-114.

Leinmüller E, Steingass H, Menke KH (1991) Tannine in Futtermitteln für Wiederkäuer. 2. Wirkungen auf den Pansenstoffwechsel in vitro. Übers. Tierernähr 19: 45-70.

Makkar HPS (1993) Anti-nutritional factors in foods for livestock. In Gill M, Owen E, Pollot GE, Lawrence TLJ (eds). Animal Production in Developing Countries. Occasional Publication No. 16. British Society of Animal Production. pp: 69-85.

Makkar HPS, Bluemmel M, Borowy, NK, Becker K (1993) Gravimetric determination of tannins and their correlations with chemical and protein precipitation methods. Journal of the Science of Food and Agriculture 61: 161-165.

McSweeney CS, Palmer B, McNeill DM, Krause DO (2001) Microbial interaction with tannins: nutritional consequences for ruminants. Animal Feed Science and Technology 91: 83-93.

Minitab (2003) v.14 user's guide II: data analysis and quality tools. Minitab, USA.

Patra AK, Kamra DN, Agarwal N (2006) Effect of plant extract on in vitro methanogenesis, enzyme activities and fermentation of feed in rumen liquor of buffalo. Animal Feed Science and Technology 128: 276-291.

Patra AK, Kamra DN, Agarwal N (2010) Effects of extracts of spices on rumen methanogenesis, enzyme activities and fermentation of feeds in vitro. Journal of the Science of Food and Agriculture 90: 511-520 
Robinson PH, Mathews MC, Fadel JG (19999) Influence of storage time and temperature on in vitro digestion of neutral detergent fiber at $48 \mathrm{~h}$, and comparison to $48 \mathrm{~h}$ in sacco neutral detergent fiber digestion. Animal Feed Science and Technology 80: 257-266.

Rodríguez R, Britos A, Rodríguez-Romero N, Fondevila M (2011) Effect of plant extracts from several tanniferous browse legumes on in vitro microbial fermentation of the tropical grass Pennisetum purpureum. Animal Feed Science and Technology 168: 188-195.

Singleton VL (1981) Naturally occurring food toxicants: phenolic substances of plant origin common in foods. Advances in Food Research 27: 149-242.

Tan HY, Sieo CC, Abdullaha N, Lianga JB, Huanga XD, Ho YW (2011) Effects of condensed tannins from Leucaena on methane production, rumen fermentation and populations of methanogens and protozoa in vitro. Animal Feed Science and Technology 169: 185-193.

Tavendale MH, Meagher LP, Pacheco D, Walker N, Attwood GT, Sivakumaran S (2005) Methane production from in vitro rumen incubations with Lotus pedunculatus and Medicago sativa, and effects of extractable condensed tannin fractions on methanogenesis. Animal Feed Science and Technology 123-124: 403-419.

Theodorou MK, Williams BA, Dhanoa MS, McAllan AB, France J (1994) A simple gas production method using a pressure transducer to determine the fermentation kinetics of ruminant feeds. Animal Feed Science and Technology 48: 185-197.

Vanlierde A, Marie-Laure V, Gengler N, Dardenne P, Froidmont E, Soyeurt H, et al. (2016) Milk mid-infrared spectra enable prediction of lactation-stage-dependent methane emissions of dairy cattle within routine population-scale milk recording schemes. Animal Production Science 56: 258-264.

Xu M, Rinkerc M, McLeoda KR, Harmon DL (2010) Yucca schidigera extract decreases in vitro methane production in a variety of forages and diets. Animal Feed Science and Technology 159: 18-26. 